\title{
BARRIERS HINDERING THE ENTRY OF NEW FIRMS TO THE COMPETITIVE MARKET AND PROFITABILITY OF INCUMBENTS
}

\author{
Xhavit Islami * \\ Vjosa Islami* \\ Marija Topuzovska Latkovikj*** \\ Enis Mulolli****
}

Received: 15. 4. 2018

Review

Accepted: 20. 10. 2019

UDC: 005.343

DOI: https://doi.org/10.30924/mjcmi.24.2.9

\begin{abstract}
Recently, entering new firms into a competitive market is getting harder due to different industry barriers. Addressing this concern, the aim of this paper is to measure the relationship between industry barriers that prevent the entry of new rivals and increase the profitability of incumbent firms. The study was based on the data of one hundred and seven executives of firms that operate in the Republic of Kosovo, and it attempts to assert and order the market entry barriers. The responses were collected by questionnaires and the econometric model was constructed, to test this relationship. The findings were obtained using descriptive statistics, Pearson correlation, and multivariate regression. Econometric results indicated that seven dimensions of industry barriers have a direct and positive
\end{abstract}

impact on the profitability of incumbents and serve as barriers for new firms to enter the market, and showed that business executives in Kosovo perceive capital requirements of non-incumbents as the most important entry barrier, whereas access to distribution channels as the least important. The theoretical and practical implications of these findings are discussed and explained.

Keywords: entry barriers; new firms; industry factors; profitability of incumbents; the competitive market.

\section{INTRODUCTION}

The first challenge faced by firms which enter the competitive market is finding an

* Xhavit Islami, Department of Management, Faculty of Economy, University "Kadri Zeka” in Gjilan, Republic of Kosovo; PhD Cand., University "Ss. Cyril and Methodius" in Skopje", Faculty of Economics, Program Organizational Sciences and Management (Management), e-mail: xhavitislami@gmail.com; xha_vit_islami@hotmail.com; xhavit.islami@uni-pr.edu.

** Vjosa Islami, Department of Management and Informatics, Faculty of Economy, University "Hasan Prishtina" in Prishtinë, Republic of Kosovo, e-mail address: vjosa_050@hotmail.com.

*** Marija Topuzovska Latkovikj, Associate Professor, Saints Cyril and Methodius University in Skopje; Institute of Sociological, Political and Juridical Research; Centre for Management and Human Resource Development, in Skopje, Republic of North Macedonia, e-mail: marija_t@isppi.ukim.edu.mk.

**** Enis Mulolli, department of Management and Informatics, Faculty of Economy, University "Hasan Prishtina" Prishtinë, Republic of Kosovo, Corresponding author, e-mail: enis.mulolli@uni-pr.edu. 
appropriate way to survive in that market. Previous studies have shown that approximately one third of the new European firms do not reach the second year of their existence, whereas fifty to sixty percent of them do not manage to survive till the seventh year (Aerts et al., 2007). New firms that try to enter into the market do the reverse activities compared to existing firms that are operating in that market. Incumbent firms are engaged in finding a way or creating a strategy that provides them with opportunities to maintain the existing position in the market as well as to increase the market share and profitability. This makes it harder for new firms to enter and to survive in the competitive market. Statistics show that about 55\% of firms fail in the first 5 years of their operation (Eurostat, 2016). According to data, about $83 \%$ of newborn enterprises in 2011 survived in 2012. Based on the Hannan \& Freeman (1984) findings, newborn organizations suffer a "liability of newness". Therefore, they have to learn how to survive despite having limited resources, and they must create successful patterns of operations (Hannan \& Freeman, 1989). The death rate of firms tends to diminish by oldness (Carroll, 1983; Baum \& Oliver, 1991).

These negative facts regarding the entry and survival of new firms in the market encouraged us to find the factors that serve as barriers for new firms to enter successfully and to operate effectively in the competitive market in Kosovo. Several authors have analyzed different factors that disturb firms to enter into the competitive market. Krasniqi (2007) analyzed the administrative burden, legal environment, tax burden, external financing and unfair competition as the critical business environment barriers. On the other hand, variations in going-firm entry from industry to industry, the possibility of entry into the industry via a series of its groups, the determinants of market-share stability within industries, conduct, and many other aspects of market structure and performance are analyzed like testable predictions by Caves \& Porter (1977). Reed (1975) and Spence (1980) presented advertising as a barrier to entering into the market; Harrigan (1981) the number of competitors; Schmalensee (1983) research and development; (Ghadar, 1982; Baumol \& Willig, 1981) sunk costs; Crawford (1975) seller concentration; Krouse (1984) brand name or trademark. But there is a lack of research measuring these relationships using empirical statistics. In response to this gap, this study finds the relationship between industry factors and its impact on incumbent profitability. The findings of this paper will enrich the existing literature by bringing new and clearer evidence for new entrepreneurs regarding the rate of danger caused by industry factors and their relationship. Firms are facing a very competitive, turbulent, and non-stable environment that stems as a result of rapid development of technology, therefore the focus of this research is to identify factors that disturb the opportunity of new firms to enter in the market. "High barriers to new firm entry simultaneously restrict access to profit generating activities for non-incumbent economic actors and insulate incumbent business owners from economic competition. Both processes limit entrepreneurial opportunities for nonincumbents" (Djankov et al., 2002).

Furthermore, the objective of this paper is: to examine the effects of industry barriers to entry on new firms in a competitive market, and to identify the importance of industry barriers on incumbents' profitability. Thus, based on the perceptions of executives of the respondent firms about the issue of industry barriers, the paper investigates issues such as: how they perceive the industry barriers as obstacles for potential new rivals, and how much these factors support 
incumbents to increase their profitability.

What does the term 'industry factors' mean? In this research, the industry factors are seen as the environment in which five Porter's forces operate, meaning rivalry among competing firms, bargaining power of suppliers, bargaining power of consumers, potential development of substitute products, potential entry of new competitors. Obstacles may be caused by these forces of industrial environment for the new firms to enter into the competitive market. It is worth mentioning that, in this study, the terms "industry" and "market" are used as substitutes (synonyms). Considering the fact that firms which try to enter the market belong to a certain industry, the term "industry" is often used instead of the word "market" (thus, in this research: "entry into the industry" is equal to "entry into the market").

The rest of this paper is organized as follows: literature review and hypotheses development are presented in the second section. Third section shows the methodology used in this study. In the fourth section, the empirical findings and hypothesis testing is presented. In the end, the fifth section includes a discussion of the findings and the sixth section provides very contributive conclusions of this study.

\section{LITERATURE REVIEW}

Threats of new entrants refers to the new firms that are potentially ready to enter the competitive market, as well as to influence the industry structure (Porter, 1980). According to, Wheelen \& Hunger (2011), new entrants are seen as a threat to an established organization because they bring new capacity, substantial resources, and a desire to gain market share. Based on this, the threats of new entry depend on the presence of entry barriers and the reaction that can be expected from incumbent firms. The intensity of competitiveness between firms increases if the new firms can easily enter into the industry (David, 2011).

For a better understanding of the entry barriers and their usage, in this part, the definitions of entry barriers in the industry for new firms are given. The main definition of this concept is attributed to the work of Bain (1956) who stated that, "a barrier to entry is an advantage of established sellers in an industry over potential entrant sellers, which is reflected in the extent to which established sellers can persistently raise their prices above competitive levels without attracting new firms to enter the industry". "An entry barrier is anything that requires an expenditure by a new entrant into an industry, but that imposes no equivalent cost upon an incumbent" Baumol \& Willig (1981). "An entry barrier is a rent that is derived from incumbency" (Gilbert, 1989). "An entry barrier is an obstruction that makes it difficult for a company to enter an industry" (Wheelen \& Hunger, 2011).Moreover, Von Weizacker (1980) and Stigler (1968) define "a barrier to entry as a cost that must be borne by a firm seeking to enter an industry but is not borne by firms already in the industry, and that implies a distortion in the allocation of resources from the social point of view". Based on the above definitions entry barriers are collections of different dimensions that try to provide a safe environment for incumbent firms and hinder new entrants in their efforts to become a part of that competitive market.

\subsection{Dimensions of industry barriers hindering new firms entry}

Previous literature provides sufficient theoretical evidence related to dimensions of industry barriers hindering new firms 
in their attempts to enter the competitive market and to increase the dominance of the incumbent firms. Authors have described these dimensions in different aspects. David (2011) described that "barriers to entry, can include the need to gain economies of scale quickly, the need to gain technology and specialized know-how, the lack of experience, strong customer loyalty, strong brand preferences, large capital requirements, lack of adequate distribution channels, government regulatory policies, tariffs, lack of access to raw materials, possession of patents, undesirable locations, counterattack by entrenched firms, and potential saturation of the market". Wheelen \& Hunger (2011) said that some of the following possible barriers to entry are: "economies of scale, product differentiation, capital requirements, switching costs, access to distribution channels, cost disadvantages independent of size, and government policy". In addition to these, Pulaj (2014) and Lundström (2019), added the reaction of existing firms, focus, and the stopping price of entry, as the new dimensions in that group of dimensions collected before. Stigler (1968) pointed out that the cost of production is a barrier of new firms to enter in the industry.

The opportunity for new firms for entering a competitive market is hindered by entry barriers and incumbent reactions in that industry. The importance of the barriers to entering in the profitability zone of incumbent firms was classified into two categories: barriers of entry created as a result of structural characteristics of industry, and barriers of entry created as a threat of eliminating new firms from existing firms' side (Pulaj, 2014).

Despite the various point of views related to entrant barriers of new firms in the market, it is crucial to explain the importance of each factor as a barrier for new entrants and as a supportive tool for incumbents. Grounded on the framework of industrial organization (IO) (Mason, 1939; Bain, 1956 and 1959), strategic management theory and entrepreneurial research suggest that barriers to entry are the main structural features of the industry that affect business performance (Hofer \& Schendel, 1978; McDougall et al., 1992).

Descriptions above provide enough evidence to analyze dimensions of industry barriers, which are used in different forms by several authors (see e.g. Porter, 1979; David, 2011; Wheelen \& Hunger, 2011; Pulaj, 2014; Lundström, 2019; Lindblad, 2019). This study will measure the impact of seven dimensions: economies of scale, product differentiation of incumbents, capital requirements of non-incumbents, switching cost, access to distribution channels, cost disadvantages independent of size, and government policy.

Economies of scale - considered by some authors as one of the most important entry barriers for new firms (Harrigan 1981; Schmalensee 1981; Yip 1982; Henderson 1984; Day 1984; Lieberman 1987). "Economies of scale refer to declines in unit costs of a product (or operation or function that goes into producing a product) as the absolute volume per period increases" (Porter, 1979), and they result from advantages associated with large firm size that facilitates lower costs per unit of output and higher efficiency (Scherer, 1970; Koch, 1974). Later, Porter (2008) claims that "supply side economies of scale arise when firms that produce at larger volumes enjoy lower costs per unit because they can spread fixed costs over more units, employ more efficient technology, or command better terms from suppliers". According to Porter (2008), "economies of scale deter 
entry by forcing the entrant to come in at large scale and risk strong reaction from existing firms or come in at a small scale and accept a cost disadvantage, both undesirable options. Scale economies can be present in nearly every function of a business, including manufacturing, purchasing, research and development, marketing, service network, sales force utilization, and distribution". For example, scale economies in production, service, marketing, and research are probably the key barriers to entry in the mainframe computer industry, as Xerox and General Electric sadly discovered (Porter, 1979).

\section{Product differentiation of incumbents-} I/O empirical research provides evidence that a high degree of product differentiation is an important barrier to entry that affects the benefits of inter-industry (Mann, 1966; Caves, 1972; Johansson \& Elg, 2002; Pehrsson, 2004; Schlegelmilch \& Ambos, 2004). Product differentiation means that established firms have brand identity and customer loyalty, which derives from past advertising, product differences, customer service, or simply from being first into the industry (Bass et al., 1978; Hofer \& Schendel, 1978; Schmalensee, 1982; Porter, 2008). For example, "corporations such as Procter \& Gamble and General Mills, which manufacture products such as Tide and Cheerios, create high entry barriers for new entrants through their high levels of advertising and promotion" (Wheelen $\&$ Hunger, 2011). Product differentiation serves as a barrier for new firms' entry because new companies must spend a lot to overcome and justify the relationship and trustfulness product- client of existing firms in the market (Pulaj, 2014). According to Bain (1959) the most significant source of barriers to entry has identified product differentiation advantages of established firms, which are strongly related to heavy advertising or other sales promotion efforts. According to him, this effort usually involves initial losses and often takes a protracted period of time. Such investments in building a brand name are particularly risky since they have no recovery value if the entry fails. Industries with a high level of product differentiation or advertising expenditures had a negative effect on the performance or success rate of new entrants (Harriga, 1983).

Capital requirements of non-incumbents - according to Shepherd (1975), Bain (1956, 1959), and Caves (1972) "capital requirements are the primary absolute-cost advantage which can serve as an important barrier to entry". The need to invest large financial resources to compete or enter the market poses barriers to entry and is higher in the capital-intensive industries (Porter 1980; Eaton \& Lipsey 1980; Harrigan 1981). The quantity of the requested capitals for new firms' entry in the market changes from one company to another. This depends on factors of technological development $(\mathrm{R} \& \mathrm{D}$, realization of the economies of scale requires a lot of capital invested) and the scale of focus (Pulaj, 2014). Meanwhile, Koch (1974) states: "Therefore, to the extent that only a few qualified entrepreneurs exist who are capable of acquiring the large amounts of capital needed in certain production processes, there may exist capital requirements that discourage the entry of new firms". The need to invest in huge financial sources, to create competition in the industry, serves as an entry barrier especially if this capital is required to be invested in commercial fields which are researchable and not justified financially or projects of development study (Porter, 1979). Porter (2008) said "whereas today's major corporations have the financial resources to enter almost any industry, the huge capital requirements in fields like computers and mineral extraction limit 
the pool of likely entrants. Even if capital is available on the capital markets, entry represents a risky use of that capital which should be reflected in risk premiums charged the prospective entrant; these constitute advantages for going firms". For example, the need to invest large financial resources into production facilities, to produce large commercial aircraft creates an important barrier to entry for any competitor to Boeing and Airbus (Wheelen \& Hunger, 2011).

Switching costs - "A barrier to entry is created by the presence of switching costs, that is, one-time costs facing the buyer in switching from one supplier's product to another's" (Porter, 2008). Switching costs forestall the buyer from the possibility of changing suppliers, and these costs are often raised or lowered by technological changes (McFarlan, 1984). According to Porter, (2008) switching costs can include cost of new ancillary equipment, employee retraining costs, need for technical help as a result of reliance on seller engineering aid, cost and time in testing or qualifying a new source, psychological costs of severing a relationship, or even product redesign. For example, once a software program like Word or Excel is placed in an office, office managers are not willing to switch to a new program, due to high training costs (Wheelen \& Hunger, 2011). (Wheelen \& Hunger, 2011). The difficulty of a new firm to gain customers has a positive relationship with enlarged switching costs (Porter, 1979).

Access to distribution channels - The need that new entrants have to secure distribution for their products can serve as a barrier to enter into the market (Porter, 2008). The intensive distribution strategies can be used by early market entrants in order to limit the access of new potential industry entrants to distributors (Porter, 1980 and 1985). "To the extent that logical distribution channels for the product have already been served by established firms, the new firm must persuade the channels to accept its product through price breaks, cooperative advertising allowances, and the like, which reduce profits" (Porter, 2008). For example, "small entrepreneurs often have difficulty obtaining supermarket shelf space for their goods because large retailers charge for space on their shelves and give priority to the established firms who can pay for the advertising needed to generate high customer demand" (Wheelen \& Hunger, 2011). According to Porter (1979), the more limited the wholesale or retail channels are, the more the existing competitors have these tied up, and obviously the tougher will be for the new entry into the industry. Furthermore, he claimed sometimes this barrier is so high that a new contestant must create its own distribution channels to surmount it.

Cost disadvantages independent of size - Sometimes, regardless of their size and attainable economies of scale, ingrained companies may have cost advantages not available to potentials rivals. These advantages can derive from the effects of the learning curve (the experience curve), access to the best raw materials sources, proprietary technology, favorable locations, assets purchased at pre-inflation prices, or government subsidies (Porter, 1979). If costs decline with experience in an industry, and if the experience can be kept proprietary by established firms, then this effect leads to an entry barrier. "Newly started firms, with no experience, will have inherently higher costs than established firms and must bear heavy startup losses from below-or near-cost pricing in order to gain the experience to achieve cost parity with established firms (if they ever can)" (Porter, 2008). The firm has a competitive advantage once the new product wins an efficient market share to be accepted 
as the standard for that type of product. "Microsoft's development of the first widely adopted operating system (MSDOS) for the IBM-type personal computer gave it a significant competitive advantage over potential competitors. Its introduction of Windows helped to cement that advantage so that the Microsoft operating system is now on more than $90 \%$ of personal computers worldwide" (Wheelen \& Hunger, 2011).

Government policy - The last major source of entry barriers is government policy (Porter, 2008). "The government can limit or even foreclose entry to industries with such controls as license requirements and limits on access to raw materials" (Wheelen \& Hunger, 2011). "The government can also play a major role by affecting entry barriers through controls such as air and water pollution standards and safety regulations" (Porter, 1979). Government limits the number of firms in a market by requiring licenses, permits, etc. (Moore 1978; Pustay 1985; Beatty et al., 1985). It is evident that in "regulated" industries, existing firms have synchronized their businesses with legal framework, making it even harder for new firms to enter the market (Pulaj, 2014). According to Pulaj (2014), it must be pointed out that the industrial structure influences are above the factor and variables that characterized competing forces outlined by Porter. In other words, entry barriers must not be prioritized according to a list of priorities which would determine the importance of individual barriers.

\subsection{Research questions and hypothesis}

As to achieve the purpose of this paper, questionnaires were carefully prepared. In accordance with this, questionnaires were mostly focused on two areas: firstly, finding out executives' perceptions on the importance of industry barriers, hindering new firms, when trying to enter the competitive market, (David, 2011), and secondly, finding out their evaluation of the industry factors that serve as entry barriers for profitability of incumbents. To find and evaluate the importance of barriers caused by industry factors that hinder the new firms in entering the competitive market, we created the following research question(s):

How do you perceive the importance of factors that in your environment may serve as barriers for new firms to entering a competitive market? (see $\mathrm{BoE}_{1} \ldots \mathrm{BoE}_{11}$ in Appendix A).

In order to measure the impact of industry barriers hindering the new entrants on the profitability of incumbent firms, the following hypothesis had to be tested:

Hypothesis $\mathrm{H}_{1}$ : Industry barriers have a direct positive relationship with the profitability of incumbent firms.

It is worth mentioning that despite numerous entry barriers, new firms find a way to enter the competitive market by higherquality products, lower prices, and substantial marketing resources. In this case: "The strategist's job, therefore, is to identify potentially new firms entering the market, to monitor the new rival firms' strategies, to counterattack as needed, and to capitalize on existing strengths and opportunities. When the risk of new firms entering the market is strong, incumbent firms generally fortify their positions and take actions to prevent new entrants, including lowering prices, extending warranties, adding features, or offering financing specials" (David \& David 2017). Griffin (2005) indicated that the advent of the Internet has reduced the costs and other barriers of entry in many market segments so the possibility of new entrants has increased for many firms in recent years. 


\section{METHODOLOGY}

The methodology of this study is a combination of primary and secondary data. Primary data are gathered by questionnaires which were distributed to the respondent firms that operate in the Republic of Kosovo. The analysis of secondary data include scientific publications and articles published by credible scientific databases, such as: Academy of Management; Science Direct, Emerald; Springer; Taylor and Francis, etc.). Special attention should be paid to secondary data. There is a difference between secondary data that could be used to test the relationship (in this case it could have been the company records, company financial statements, or their bookkeeping) and secondary data for literature review (articles and studies).

It is necessary to state that there are differences between industries regarding barriers to entry and that it is possible that results would be different if divided depending on the industry. This study measures the entry barriers based on the executives' perceptions of responded organizations that focus their activity in the manufacturing sector. The data that were gathered in 2017 by self-administered questionnaires, were run through IBM SPSS program to find the relationship between variables. The respondent firms were randomly chosen. The same methodology for the same kind of measurements was used before (Niu et al., 2012; Mulolli et al., 2015; Islami et al., 2018; Mustafa et al., 2019).

\subsection{Data collection}

From 170 questionnaires in total that were distributed to managers, only 107 of them had contained valid data (the scale of responses was 62.9\%). Even though 126 filled questionnaires were returned, 19 of them lacked data and could not be entered in the further analysis; therefore, only 107 questionnaires with full data were analyzed.
In order to get the data from respondents, questionnaires were divided in three parts: (a) the first part was focused on obtaining the participants' demographic characteristics; (b) the second part was focused on identifying the entry barriers in terms of perceived importance by executives, the 11 statements were distributed in the questionnaires and the answers required to rate them from "not important at all" - scored as 1 to "extremely important" - scored as 5; (c) the third part was designed to relate the industry barriers and profitability of incumbents; in this part industry barriers are represented by 8 dimensions and 32 items. The scale used in the questionnaire is based on the five point Likert -scale ("not important at all" - scored as 1 to "extremely important" - scored as 5).

\subsection{Variables of this study}

List of barriers that are presented by eleven research questions / statements $\mathrm{BoE}_{1} \ldots \mathrm{BoE}_{11}$, were adapted from David (2011), who investigated the importance of these barriers on hindering of new firms in the competitive market. These research questions tried to obtain the respondent firms' executives' perceptions of importance of these factors in preventing the nonincumbent firms to enter Kosovo's competitive market.

For measuring the impact of the industry barriers on the profitability of incumbents, dimensions were adapted from previous studies (Porter, 1979; David, 2011; Wheelen \& Hunger, 2011; Pulaj, 2014; Lundström, 2019; Lindblad, 2019). Independent variables of this study are: economies of scale (ES), product differentiation of incumbents (PDI), capital requirements of non-incumbents (CR), switching costs (SC), access to distribution channels (ADC), cost disadvantages independent of size (CD), and government policy (GP). The dependent variable is the profitability of incumbents (PI). To measure this 
relationship in questionnaires, dimensions are represented by eight variables and thirty two items, most of them adapted from previous studies (Karakaya \& Stahl 1989, 1992; Karakaya, 2002; Niu et al., 2012; Lindblad, 2019). Other items that were important to explain more specifically this relationship were added by authors of this study.

\subsection{The model used}

The model used is similar in method to the model used by Niu et al. (2012). In this section we constructed an econometric model multiple regression in order to estimate the impact of industry barriers on profitability of incumbents.

$$
\begin{aligned}
& Y=X \beta+\varepsilon \\
& X \beta=\beta_{0}+\beta_{I} x_{1+} \beta_{2} x_{2} \ldots . .+\beta_{n} x_{n} \\
& Y=\beta_{0}+\beta_{I} x_{1+} \beta_{2} x_{2} \ldots .+\beta_{n} x_{n}+\varepsilon
\end{aligned}
$$

Note: $\hat{Y}=$ dependent variable, $\boldsymbol{\beta}_{0}=$ nonstandardized coefficients (constant), $\beta_{1 \ldots . \mathrm{n}}=$ non-standardized coefficient of variables, $\mathrm{x}_{1 \ldots \mathrm{n}}=$ independent variables, $\varepsilon_{\mathrm{i}}=$ standard error.

Based on non-standardized weights of regression, regression equation for dependent variable "profitability of incumbents" can be presented as:

$\hat{Y}=\beta_{0}+\beta_{1} E S+\beta_{2} P D I+\beta_{3} C R+\beta_{4} C S+$ $\beta_{5} A D C+\beta_{6} C D+\beta_{7} G P+\varepsilon$

\subsection{Demographic data of respondent firms}

The data of participants' demographic characteristics such as size, age, and the position of the surveyed subject, is featured in Table 1.

Table 1: Demographic characteristic of the respondent firms

\begin{tabular}{|l|ll|}
\hline \multicolumn{2}{|l|}{ Demographic variable } & \multicolumn{2}{l|}{ Count (percentage) $\mathrm{n}=107$} \\
\hline Firm's size & 58 & $(54.2 \%)$ \\
\hline Up to 49 employees & 49 & $(45.8 \%)$ \\
\hline From 49-250 employee & \multicolumn{2}{|l|}{} \\
\hline Age of firm & 49 & $(45.8 \%)$ \\
\hline $1-10$ years & 36 & $(33.7 \%)$ \\
\hline $11-20$ years & 9 & $(8.4 \%)$ \\
\hline $21-30$ years & 8 & $(7.5 \%)$ \\
\hline $31-40$ years & 5 & $(4.6 \%)$ \\
\hline Over 40 years & 13 & $(12.2 \%)$ \\
\hline Position in firm of the filler of the questionnaire \\
\hline Owner & 45 & $(42 \%)$ \\
\hline Director (CEO) & 49 & $(45.8 \%)$ \\
\hline Manager & \multicolumn{2}{|l|}{} \\
\hline $\begin{array}{l}\text { Questionnaire fillers experience } \\
\text { organizational management }\end{array}$ & \multicolumn{2}{|l|}{} \\
\hline 1-5 years & 6 & $(5.7 \%)$ \\
\hline 6-10 years & 17 & $(15.8 \%)$ \\
\hline
\end{tabular}


Journal of Contemporary Management Issues

\begin{tabular}{|l|ll|}
\hline $10-15$ years & 54 & $(50.4 \%)$ \\
\hline $16-20$ years & 23 & $(21.6 \%)$ \\
\hline Over 20 years & 7 & $(6.5 \%)$ \\
\hline
\end{tabular}

Source: authors

As Table 1 shows, more than $50 \%$ of the respondent firms are over 11 years old and $45.8 \%$ are $1-10$ years old, but it is worth mentioning that inside the continuum 1-10 years there are only 7 firms $(6.5 \%)$ that are (relatively) new firms (e.g. 1-3 years old). Also, about $80 \%$ of the executives who fill the questionnaires had managerial experience of over 10 years. These facts are directly related to the content of the paper and indicate that the conclusions of this paper are presented based on incumbent firms' attitudes, not on new firms.

\section{EMPIRICAL FINDINGS}

The data gathered by questionnaires are analyzed in a three-part process in order to get the final results and provide optimal conditions to test the research hypothesis.
In part (a) the validity test of constructs is done to find which items can be included as variables (validation of first-order constructs and validation of second-order constructs); part (b) includes correlation analysis between testable variables to find the possible multicollinearity among variables, and in part (c), after the two of previous conditions were fulfilled, the multivariate regression analysis is used to test the relationship between variables.

\subsection{Descriptive data}

Descriptive data presented in Table 2, show minimum value, maximum value, average, and standard deviation, for the statements that were required by managers to find out their perception of the importance of barriers in hindering new firms while entering in the market.

Table 2: Descriptive statistics $(\mathrm{n}=107)$

\begin{tabular}{|c|c|c|c|c|}
\hline Study variables & Minimum & Maximum & Mean & Standard deviation \\
\hline $\mathrm{BoE}_{1}$ & 1 & 5 & 3.483 & 1.277 \\
\hline $\mathrm{BoE}_{2}$ & 1 & 5 & 3.685 & 1.340 \\
\hline $\mathrm{BoE}_{3}$ & 1 & 5 & 3.902 & 1.289 \\
\hline $\mathrm{BoE}_{4}$ & 2 & 5 & 4.234 & 1.078 \\
\hline $\mathrm{BoE}_{5}$ & 2 & 5 & 4.039 & 1.609 \\
\hline $\mathrm{BoE}_{6}$ & 1 & 5 & 3.815 & 1.365 \\
\hline $\mathrm{BoE}_{7}$ & 1 & 5 & 3.554 & 1.596 \\
\hline $\mathrm{BoE}_{8}$ & 1 & 5 & 3.457 & 1.616 \\
\hline $\mathrm{BoE}_{9}$ & 2 & 5 & 3.773 & 1.614 \\
\hline $\mathrm{BoE}_{10}$ & 1 & 5 & 3.901 & 1.387 \\
\hline $\mathrm{BoE}_{11}$ & 1 & 4 & 2.712 & 1.644 \\
\hline
\end{tabular}

Source: authors 
Figure 1: Importance of entry barriers for new firms by respondent executive perception

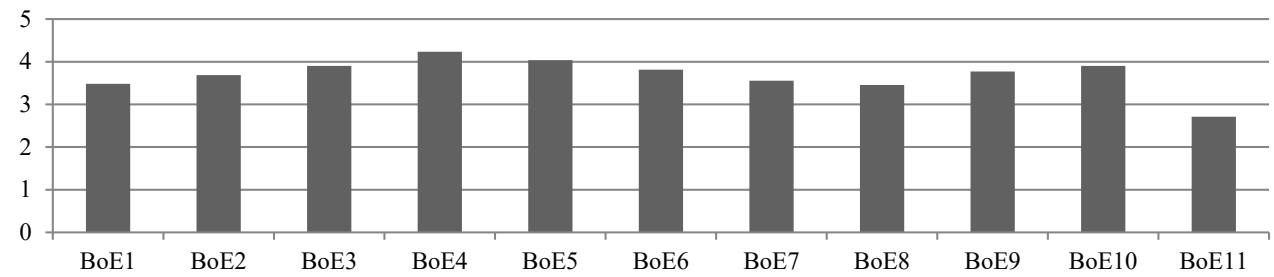

Source: authors

As shown in Figure 1, the entry barriers used by David (2011) are evaluated as very high obstacles even for Kosovo environment, and this increases the certainty that questionnaires were filled by responsible persons who know the competitive environment. Results in Figure 1 indicate that the respondents perceived that high capital required for new firms to enter the competitive market serve as the most important barrier, whereas the statement "if firms operating in the same industry have excess capacity and inventory" was perceived as the least important factor that serves as an entry barrier for new entrants.

\subsection{Convergent and discriminant validity}

According to Hair et al. (2010) the value of factor loading for each item should be more than 0.4 . Table 3 shows the relationships between the items that are measured to see which items can be represented by the variables. In order to determine which factors are included within each variable, Cron- bach's alpha test for reliability was implemented (see Table 3). Reliability analysis was done using Cronbach's alpha for principal components factor analysis matrix of: (a) economies of scale, (b) product differentiation of incumbents, (c) capital requirements of non-incumbents, (d) switching cost, (e) access to distribution channels, (f) cost disadvantages independent of size, (g) government policy, and (h) profitability of incumbents. For simplicity, only loadings above 0.4 are displayed on Table 3 (items that had the value under 0.4 were eliminated in order to have a better estimate of the model and to provide a closer fit). The capital requirements of non-incumbents (CR) construct initially was represented by 5 items. After validation of first-order constructs the item $\mathrm{CR} / \mathrm{BS}_{5}$ loaded the factor under 0.4 , so this item was removed for further analysis. Also, switching cost (SC) construct initially was represented by 4 items. After validation of first-order constructs the item $\mathrm{SC} / \mathrm{SC}_{4}$ loaded the factor under 0.4 , so this item was removed from further analysis.

Table 3: Factor loadings

\begin{tabular}{|c|c|c|c|c|c|c|c|}
\hline Item & $\mathrm{F}_{1}$-ES & $\mathrm{F}_{2}-\mathrm{PDI}$ & $\mathrm{F}_{3}-\mathrm{CR}$ & $\mathrm{F}_{4}-\mathrm{SC}$ & $\mathrm{F}_{5}-\mathrm{ADC}$ & $\mathrm{F}_{6}-\mathrm{CD}$ & $\mathrm{F}_{7}-\mathrm{GP}$ \\
\hline \multicolumn{8}{|c|}{ Economies of scale (ES) } \\
\hline $\mathrm{ES} / \mathrm{LA}_{1}$ & 0.642 & & & & & & \\
\hline $\mathrm{ES} / \mathrm{LC}_{2}$ & 0.721 & & & & & & \\
\hline $\mathrm{ES} / \mathrm{CA}_{3}$ & 0.695 & & & & & & \\
\hline $\mathrm{ES} / \mathrm{LP}_{4}$ & 0.705 & & & & & & \\
\hline \multicolumn{8}{|c|}{ Product differentiation of incumbents (PDI) } \\
\hline $\mathrm{PDI} / \mathrm{HA}_{1}$ & & 0.594 & & & & & \\
\hline
\end{tabular}


Journal of Contemporary Management Issues

\begin{tabular}{|c|c|c|c|c|c|c|c|}
\hline $\mathrm{PDI} / \mathrm{PC}_{2}$ & & 0.628 & & & & & \\
\hline $\mathrm{PDI} / \mathrm{BN}_{3}$ & & 0.754 & & & & & \\
\hline $\mathrm{PDI} / \mathrm{BA}_{4}$ & & 0.728 & & & & & \\
\hline $\mathrm{PDI} / \mathrm{SP}_{5}$ & & 0.657 & & & & & \\
\hline \multicolumn{8}{|c|}{$\begin{array}{l}\text { Capital requirements of non-incumbents } \\
(C R)\end{array}$} \\
\hline $\mathrm{CR} / \mathrm{AE}_{1}$ & & & 0.831 & & & & \\
\hline $\mathrm{CR} / \mathrm{CE}_{2}$ & & & 0.745 & & & & \\
\hline $\mathrm{CR} / \mathrm{RD}_{3}$ & & & 0.832 & & & & \\
\hline $\mathrm{CR} / \mathrm{SC}_{4}$ & & & 0.713 & & & & \\
\hline \multicolumn{8}{|c|}{ Switching cost (SC) } \\
\hline $\mathrm{SC} / \mathrm{CS}_{1}$ & & & & 0.660 & & & \\
\hline $\mathrm{SC} / \mathrm{CL}_{2}$ & & & & 0.761 & & & \\
\hline $\mathrm{SC} / \mathrm{EP}_{3}$ & & & & 0.631 & & & \\
\hline \multicolumn{8}{|c|}{$\begin{array}{l}\text { Access to distribution channels } \\
(A D C)\end{array}$} \\
\hline $\mathrm{ADC} / \mathrm{AD}_{1}$ & & & & & 0.563 & & \\
\hline $\mathrm{ADC} / \mathrm{CC}_{2}$ & & & & & 0.489 & & \\
\hline $\mathrm{ADC} / \mathrm{MM}_{3}$ & & & & & 0.576 & & \\
\hline $\mathrm{ADC} / \mathrm{NF}_{4}$ & & & & & 0.547 & & \\
\hline \multicolumn{8}{|c|}{$\begin{array}{l}\text { Cost disadvantages independent of size } \\
\text { (CD) }\end{array}$} \\
\hline $\mathrm{CD} / \mathrm{IP}_{1}$ & & & & & & 0.625 & \\
\hline $\mathrm{CD} / \mathrm{IR}_{2}$ & & & & & & 0.672 & \\
\hline $\mathrm{CD} / \mathrm{IP}_{3}$ & & & & & & 0.710 & \\
\hline $\mathrm{CD} / \mathrm{TS}_{4}$ & & & & & & 0.697 & \\
\hline \multicolumn{8}{|c|}{$\begin{array}{l}\text { Government policy } \\
(G P)\end{array}$} \\
\hline $\mathrm{GP}^{-\mathrm{EP}_{1}}$ & & & & & & & 0.568 \\
\hline $\mathrm{GP} / \mathrm{GL}_{2}$ & & & & & & & 0.742 \\
\hline $\mathrm{GP} / \mathrm{GS}_{3}$ & & & & & & & 0.685 \\
\hline Item & $\mathrm{F}_{1}-\mathrm{PI}$ & & & & & & \\
\hline \multicolumn{8}{|c|}{ Profitability of incumbents (PI) } \\
\hline $\mathrm{PI}_{1}$ & 0.827 & & & & & & \\
\hline $\mathrm{PI}_{2}$ & 0.843 & & & & & & \\
\hline $\mathrm{PI}_{3}$ & 0.855 & & & & & & \\
\hline
\end{tabular}

Source: authors 


\subsection{Correlation analysis}

According to results provided in the Table 4, relationships among independent variable are inside the acceptable intervals. These results allowed us to proceed to test the multivariate regression analysis. Following that, it was found that the relationship between variables is between values $(+,-0.7)$. According to general rules for obtaining correlations, if the value is outside these limits, variables have strong connection between them and that the regression produces incorrect estimates. A high correlation between independent variables causes multicollinearity effect (Hair at al., 1998; Lind et al., 2002).

Table 4: Mean, standard deviations, and correlations matrix of independent variables $(n=107)$

\begin{tabular}{|l|l|l|l|l|l|l|l|l|l|}
\hline Variables & Mean & SD & 1 & 2 & 3 & 4 & 5 & 6 & 7 \\
\hline Economies of scale & 4.023 & 1.685 & - & & & & & & \\
\hline $\begin{array}{l}\text { Product differentia- } \\
\text { tion of incumbents }\end{array}$ & 2.965 & 1.349 & $.513^{* *}$ & - & & & & & \\
\hline $\begin{array}{l}\text { Capital } \\
\text { requirements of non- } \\
\text { incumbents }\end{array}$ & 3.659 & 1.231 & .201 & $.443^{* *}$ & - & & & & \\
\hline Switching cost & 3.428 & 1.293 & $.505^{* *}$ & $.336^{* *}$ & $.674^{* *}$ & - & & & \\
\hline $\begin{array}{l}\text { Access to } \\
\text { distribution } \\
\text { channels }\end{array}$ & 3.985 & 1.112 & .035 & -.421 & -.022 & .321 & - & & \\
\hline $\begin{array}{l}\text { Cost disadvantages } \\
\text { independent of size }\end{array}$ & 3.521 & 1.232 & $.620^{* *}$ & $.252^{*}$ & $.427^{* *}$ & $.289^{*}$ & $.368^{*}$ & - & \\
\hline $\begin{array}{l}\text { Government policy } \\
\text { Governen }\end{array}$ & 3.836 & 1.647 & $.295^{* *}$ & $.531^{* *}$ & $.520^{*}$ & $.653^{* *}$ & $.431^{*}$ & .074 & - \\
\hline
\end{tabular}

Source: authors

**. Correlation is significant at the 0.01 level (2-tailed)

*. Correlation is significant at the 0.05 level (2-tailed)

\subsection{Multivariate regression analysis}

Finally, the scores of seventh components of industry barriers were regressed over the scores of access to the profitability of incumbents and their effect was captured.
According to regression analysis independent variables that enter in analysis explain $48.2 \%$ of dependent variable "profitability of incumbents". The model is important statistically with the significance level $\alpha=0.05$.

Table 5: Regression results of industry barriers access to the profitability of incumbents $(n=107)$

\begin{tabular}{|c|c|c|c|c|}
\hline Causal path & Estimate $\beta$ & S.E & $\mathbf{t}$ & p-value \\
\hline Constant & 0.425 & 0.284 & 2.540 & 0.3221 \\
\hline ES & $0.653 * *$ & 0.075 & 2.947 & 0.0031 \\
\hline PDI PI & $0.242 *$ & 0.068 & 2.851 & 0.0159 \\
\hline CR PI & $0.674 *$ & 0.055 & 2.134 & 0.0466 \\
\hline SC PI & $0.388^{*}$ & 0.072 & 2.635 & 0.0225 \\
\hline ADC PI & $0.112 * *$ & 0.028 & 3.148 & 0.0028 \\
\hline $\mathrm{CD}$ & $0.439^{*}$ & 0.097 & 2.243 & 0.0432 \\
\hline
\end{tabular}


Journal of Contemporary Management Issues

\begin{tabular}{|c|c|c|c|c|}
\hline GP PI & $0.317^{*}$ & 0.083 & 2.592 & 0.0285 \\
\hline \multicolumn{2}{|c|}{$\mathbf{R}^{2}$} & 0.497 & & \\
\hline$\Delta \mathbf{R}^{2}$ & 0.482 & & \\
\hline
\end{tabular}

** at 0.01 level of significance; * at 0.05 level of significance

Source: authors

Results indicated that economies of scale has a direct positive impact on profitability of incumbents (estimate $=0.653$, $p=0.0031)$, in the empirical estimation, the economies of scale increases by one unit, their access to the profitability of incumbents will increase by 0.653 units. The same interpretation is valuable for other relationships between variables, as is shown in Table 5. As the results indicated, the increased level of industry barriers that were treated in this study such as: the economies of scale, product differentiation on incumbents, capital requirements of non-incumbents, switching costs, access to distribution channels, cost disadvantages independent of size, and government policy, improve the profitability of incumbents. This situation reduces the opportunity of rivals to enter in the competitive market, while increasing the profitability of incumbents.

\section{DISCUSSION OF FINDINGS}

The aim of the study was to identify the relationship of industry barriers hindering the new firms while entering the competitive market and increase the profitability of incumbents. To find the importance of industry barriers in a competitive market, the study was focused in two directions. On one side, it was required by executives of organizations to show their perception of several factors/barriers that can serve as obstacles for new firms. Whereas, on the other side, they were required to evaluate the impact of barriers in their firm profitability. In order to simplify the analysis, the first perception is measure by average of their question to see their perceived for that barriers for new firms. These two directions are in direct relation to each other, hindering new firms in entering the competitive market means for incumbents to have more consumers compared to the markets where new firms enter easily in that market. Also, by increasing profitability of incumbent firms means more resources to create defense strategies and to increase the barriers for new firms to enter in competitive market.

\subsection{Importance of entry barriers}

All statements presented as entry barriers from David (2011), have been perceived by executives in the Kosovo market. Executives' perceptions were that the existing channels to distribute the products of incumbent firms create an additional industry barrier for new firms to enter the market. Furthermore, having a favorable location by incumbent firms complicates, even more, the entry of new firms to the competitive market. As a result of this, if these factors are present in the industry, it represents a difficulty for the new firms to enter in the market.

It can be said that the increase of governmental barriers for new firms to enter in the market, such as imposing licenses and permissions to new firms, leads to the rise of other barriers for new entrants, such as: more investment in buildings, equipment and machines, which are required in order to satisfy licensing requirements. As a consequence, 
if the barriers caused by governmental rules exist, this situation provokes the need of new entrants for higher investment that make it even more difficult to enter the industry. Moreover, executives' evaluation was that a strong competition between existing firms in the industry may cause other barriers that increase the difficulty for new entries, especially when determined by the law or government-enforced barriers. This obstacle derives as a consequence of government policies that are oriented towards developing another industry, which had been blocked, or where monopoly existed and they try to bring free competition. This phenomenon occurs in situations when a country wants to develop an industry in which has a competitive advantage, compared to other countries and tries to direct all resources toward that industry. Consequently, to beat rivals in order that as the "market leader" to enjoy the total benefits of the market. If the foreign company has a competitive advantage, they can bring to another country their products cheaper than domestic firms and the consumers might buy the imported product because of a favorable price. This situation leads to the failure of domestic firms, as they do not have a competitive advantage compared to foreign firms. So, as a consequence, the government is pushed to create barriers for new firms that do not have a competitive advantage to enter into the industry. It should be noted that this kind of barrier is against the free market, and this situation happens rarely.
Often incumbent firms start to make special offers and decrease their product price to discourage the new entrants and to make it harder for them to get in, this way they create a barrier for new entrants. In that situation, new firms in order to enter the market have to invest more in buildings, equipment, and machines to compete with the existing firms or they must pursue the differentiation strategy. The first approach, increasing the investment, is a big challenge for new firms and it could serve as a barrier in the early stage, as they do not have enough resources to invest and, as a consequence, this does not offer them any facility to enter the industry. Following the second path, differentiation strategy, requires something new to be brought to the market, which is costly, as well. The large numbers of incumbents in that industry encourage firms to compete by a special offer or low-price, which damages the goal of new firms to get into the competitive market. In addition, the low demand for the industry products does not lead to the situation when new firms demand to enter the market, because the decrease in demand of the products does not increase the desire of new firms to enter into that industry. Therefore, when the barrier to entry in the industry of new firms is a low demand for the product, in this case, it can be said that the obstacle to entering the industry for new firms is not the industry environment but the low motivation of entrepreneurs to get into such a non-profitable industry.

Table 6: Empirical verification of questionnaire items (David, 2011)

\begin{tabular}{|c|l|l|}
\hline General & \multicolumn{1}{|c|}{ Statement } & Authentication \\
\hline $\begin{array}{l}\text { Research } \\
\text { question: }\end{array}$ & $\begin{array}{l}\text { How do you perceive the importance of factors/statements } \\
\left(\mathrm{BoE}_{1} \text { to } \mathrm{BoE}_{11}\right) \text { that in your environment may serve as bar- } \\
\text { riers for new firms to entry in competitive market? }\end{array}$ & $\begin{array}{l}\text { Supported, all the } \\
\text { statement have an av- } \\
\text { erage above }(>2.5) .\end{array}$ \\
\hline
\end{tabular}

Source: authors 


\section{Journal of Contemporary Management Issues}

\subsection{The impact of industry barriers on incumbent profitability}

The second part of the discussion is focused on the impact of seven industry barriers in the profitability of incumbents. To make this paper more valuable and to meet the full aim of the paper, the relationship between industry barriers and profitability of incumbents was found. In this paper, we have evidenced that industry barriers have positive impact on increasing incumbents' profitability. The results in Table 5 indicated that a direct positive impact on industry barriers on the profitability of incumbents exists, hence the first hypothesis was accepted $\left(\mathrm{H}_{1} \uparrow\right)$.

As seen in the results presented in Table 5 , capital requirements of non-incumbents have been considered as the most important factor that hinders new firms entering the competitive market, consequently increasing the profitability of incumbents. Currently, globalization and free trade agreements between countries have moved the competition to the next level. Large and powerful international companies compete freely in other countries and this makes it very hard for new firms to enter the market.

Derived by regression analysis, all these relationships support incumbents and go against the new entrants in the industry. Based on this, it can be said that: as much as the industry barriers are applicable, they expose the fight against the opportunity of new entrants into the competitive market. By nature, incumbents are focused to extend more the existing market and to hold the price as higher as possible, by keeping out the rivals. Also, the result of Table 5 indicated that increasing the profitability of incumbents by applying the industry barriers makes the incumbents stronger and more powerful against the new entrants. As a result, the segregation between incumbents and new entrants in the competitive market become deeper. The losers in this position are the buyers because the incumbents hold the price up, the rivals cannot get in the market to make pressure to put down the price. In Table 7, the empirical verification of tested hypothesis of this study is presented.

Table 7. Empirical verification of tested hypothesis

\begin{tabular}{|c|l|c|}
\hline Hypothesis & \multicolumn{1}{|c|}{ Statement } & Empirical verification \\
\hline Hypothesis $\left(H_{l}\right)$ & $\begin{array}{l}\text { Industry barriers have a direct positive relation- } \\
\text { ship with the profitability of incumbents. }\end{array}$ & Supported \\
\hline
\end{tabular}

Source: authors

\section{CONCLUSIONS}

To sum up, this study presents the literature review of industry factors that serve as barriers for new firms to enter the competitive market, verified by empirical results. The aim of this paper was to measure the effect of industry barriers hindering new firms when entering the competitive market on the profitability of incumbents. To provide the final results and to realize the aim of this study, one hundred and seven (107) executives of firms that operate in the Republic of Kosovo have participated. Findings of this paper indicated that industry barriers help the incumbents to increase their profitability and serve as obstacles for rivals to enter in the market. Regression analysis indicated that all industry barriers that were tested in this study such as: economies of scale, product differentiation on incumbents, capital requirements of non-incumbents, 
switching costs, access to distribution channels, cost disadvantages independent of size, and the government policy, have a direct positive impact on the profitability of incumbents, and make it harder for new entrants to get into the industry, so the hypothesis was accepted. The perceived most important barrier to increasing the profitability of incumbent firms and hindering non-incumbents in entering the competitive market was the capital requirement of non-incumbent firms, whereas distribution channels were perceived as the least important. Results of this study make a significant contribution to the scientific and academic circle, regarding the relationship of industry factors as barriers for new firms to enter in the market in Kosovo, in the region and beyond.

\section{IMPLICATIONS FOR PRACTITIONERS AND RESEARCHERS}

The current research validates the industry barriers that have largely been poorly defined and on whose importance there has been a high degree of inconsistency in understanding. While some firms have understood the importance of industry barriers, they often do not know exactly what is the impact of each barrier on their firm profitability, due to a lack of understanding of the factors, which cause an increment of incumbent profitability. By suggesting and empirically verifying the industry barriers, measuring the incumbent profitability and by demonstrating their impact on enhancing obstacles for entering the competitive market, the current study provides firm managers with a useful instrument for integrating the examination of industry barriers to analysis of incumbent profitability of incumbents and the difficulties encountered by non-incumbents to enter the market.
The findings of this research support the view that using industry barriers can have a visible impact on the profitability of incumbents and on hindering of new firms to enter the market. The advice that stems from the results of this research, which can serve as a good way for firm managers to start to measure the industry barriers on their firm profitability, or for entrepreneurs who want to enter into the competitive market, but do not know the challenges/barriers, should follow these steps: (a) examining the seven barriers presented in this research; (b) measuring the impact of each barrier depending on individual situation; and (c) creating a clear strategy for overcoming these barriers.

\section{REFERENCES}

1. Aerts, K., Matthyssens, P., \& Vandenbempt, K. (2007). Critical role and screening practices of European business incubators. Technovation, 27(5), 254-267. Doi:10.1016/j. technovation.2006.12.002

2. Bain, J. S. (1956). Barriers to new competition (Vol. 3, p. 55). Cambridge, MA: Harvard University Press. Doi:10.4159/harvard.9780674188037

3. Bain, J. S. (1959). Industrial Organization. John Wiley \& Sons, Inc,New York.

4. Bass, F. M., Cattin, P., \& Wittink, D. R. (1978). Firm effects and industry effects in the analysis of market structure and profitability. Journal of Marketing Research, 15(1), 3-10. Doi:10.2307/3150395

5. Baum, J. A. C., \& Oliver, C. (1991). Institutional linkages and organizational mortality. Administrative Science Quarterly, 36(2), 187-218. Doi:10.2307/2393353

6. Baumol, W. J., \& Willig, R. D. (1981). Fixed costs, sunk costs, entry barriers, 
and sustainability of monopoly. The Quarterly Journal of Economics, 96(3), 405-431. Doi:10.2307/1882680

7. Beatty, R. P., Reim, J. F., \& Schapperle, R. (1985). The effect of entry on bank shareholder wealth: Implications for interstate banking. Journal of Banking Research, 16(1), 8-15.

8. Carroll, G. R. (1983). A stochastic model of organizational mortality: Review and reanalysis. Social Sciences Research, 12(4), 303-329. Doi:10.1016/0049-089x(83)90022-4

9. Caves, R. E. (1972). American industry: Structure, conduct, performance (No. HC 106.5. C38 1972).

10. Caves, R. E., \& Porter, M. E. (1977). From entry barriers to mobility barriers: Conjectural decisions and contrived deterrence to new competition. The quarterly journal of economics, 91(2), 241-261. Doi: $10.2307 / 1885416$

11. Crawford, J. (1975). Seller concentration, entry barriers, and profit margins: a comment. Industrial Organization Review, 3(3), 176-8.

12. David, F. R. (2011). Strategic management: Concepts and cases. Pearson/ Prentice Hall, (13th ed.).

13. David, F. R., \& David, F.R. (2017). Strategic management: Concepts and cases. Pearson/Prentice Hall, (16th ed.).

14. Day, G. S. (1984). Strategic market planning: The pursuit of competitive advantage. West Group.

15. Djankov, S., La Porta, R., Lopez-deSilanes, F., \& Shleifer, A. (2002). The regulation of entry. The quarterly Journal of economics, 117(1), 1-37.

16. Eaton, B. C., \& Lipsey, R. G. (1980). Exit barriers are entry barriers: the durability of capital as a barrier to entry. The Bell Journal of Economics, 11(2), 721-729. Doi:10.2307/3003391

17. Eurostat statistic explained (2016), Web: looked 22.01.2018, https:// ec.europa.eu/eurostat/statistics-explained/index.php?title $=$ Business_demography_statistics

18. Ghadar, F. (1982). Political Risk and the Erosion of Control-The Case of the Oil Industry. Columbia Journal of World Business, 17(3), 47-51.

19. Gilbert, R. J. (1989). Mobility barriers and the value of incumbency. Handbook of industrial organization, 1, 475-535. Doi:10.1016/ s1573-448x(89)01011-3

20. Griffin, R. W. (2005). Management (Eighth Edition). Published by Biztantra, New Delhi.

21. Hair, J. F., Anderson, R. E., Babin, B. J., \& Black, W. C. (2010). Multivariate data analysis: A global perspective (Seventh Edition), Pearson, New York.

22. Hair, J. F., Anderson, R. E., Tatham, R. L., \& Back, W. C. (1998). Multivariate data analysis (Fifth Edition). New Jersey: Prentice Hall.

23. Hannan, M. T., \& Freeman, J. (1984). Structural inertia and organizational change. American Sociological Review, 49, 149-164. Doi:10.2307/2095567

24. Hannan, M. T., \& Freeman, J. (1989). Organizational ecology. Cambridge, MA: Harvard University Press.

25. Harrigan, K. R. (1981). Barriers to entry and competitive strategies. Strategic Management Journal, 2(4), 395-412. Doi:10.1002/smj.4250020407

26. Harrigan, K. R. (1983). Entry barriers in mature manufacturing industries. Advances in Strategic Management, 2(1), 67-97. 
27. Henderson, B. D. (1984). The application and misapplication of the experience curve. Journal of Business Strategy, 4(3), 3-9. Doi:10.1108/eb039027

28. Hofer, C. W., and Dan Schendel (1978). Strategy formulation: Analytic concepts. St. Paul, Minnesota: West Publishing Company.

29. Islami, X., Mulolli, E., \& Mustafa, N. (2018). Using Management by Objectives as a performance appraisal tool for employee satisfaction. $F u$ ture Business Journal, 4(1), 94-108. Doi:10.1016/j.fbj.2018.01.001

30. Johansson, U., \& Elg, U. (2002). Relationships as entry barriers: a network perspective. Scandinavian Journal of Management, 18(3), 393-419. Doi:10.1016/s0956-5221(01)00014-8

31. Karakaya, F. (2002). Barriers to entry in industrial markets. Journal of Business \& Industrial Marketing, 17(5), 379-388. Doi:10.1108/08858620210439059

32. Karakaya, F., \& Stahl, M. J. (1989). Barriers to entry and market entry decisions in consumer and industrial goods markets. Journal of marketing, 53(2), 80-91. Doi:10.2307/1251415

33. Karakaya, F., \& Stahl, M. J. (1992). Underlying dimensions of barriers to market entry in consumer goods markets. Journal of the Academy of Marketing Science, 20(3), 275-278. Doi:10.1177/0092070392203010

34. Koch, J. (1974). Industrial organization and price, Englewood Cliff.

35. Krasniqi, B. A. (2007). Barriers to entrepreneurship and SME growth in transition: the case of Kosova. Journal of Developmental Entrepreneurship, 12(01), 71-94. Doi:10.1142/ s1084946707000563

36. Krouse, C. G. (1984). Brand name as a barrier to entry: The Rea lemon case. Southern Economic Journal, 51(2), 495-502. Doi:10.2307/1057827

37. Lieberman, M. B. (1987). The learning curve, diffusion, and competitive strategy. Strategic management journal, 8(5), 441-452. Doi:10.1002/ smj.4250080504

38. Lind, D. A., Marchal, W. G., \& Mason, R. D. (2002). Statistical techniques in business \& economics (eleventh edition). New York, United States: McGraw-Hill Irwin.

39. Lindblad, F. (2019). Market development barriers for the Swedish wooden multi-family house industry. International Journal of Engineering and Technology, 11(3), 187-195. Doi:10.7763/ijet.2019.v11.1145

40. Lundström, K. (2019). Market entry to Sweden in district heating industry: the case of W1TT Group Oy. Tampere University of Applied Sciences, Finland.

41. Mann, H. M. (1966). Seller concentration, barriers to entry, and rates of return in thirty industries, 1950-1960. The Review of Economics and Statistics, 48(3), 296-307. Doi:10.2307/1927085

42. Mason, E. S. (1939). Price and production policies of large-scale enterprise. The American Economic Review, 29(1), 61-74.

43. McDougall, P. P., Robinson Jr, R. B., \& DeNisi, A. S. (1992). Modeling new venture performance: An analysis of new venture strategy, industry structure, and venture origin. Journal of Business Venturing, 7(4), 267-289. Doi:10.1016/0883-9026(92)90002-9

44. McFarlan, F. W. (1984). Information Technology Changes the Way You Compete. Harvard Business Review, 62 (May-June), 98-103. 
45. Moore, T. G. (1978). The beneficiaries of trucking regulation. The Journal of Law and Economics, 21(2), 327-343. Doi:10.1086/466923

46. Mulolli, E., Islami, X., \& Skenderi, N. (2015). Human resource management practices and SMEs performance: study based in Kosovo. International Review of Management and Business Research, 4(4), 1171-1180.

47. Mustafa, N., Nakov, L., \& Islami, X. (2019). The impact of organizational changes on increasing SMEs competitiveness, Acta Universitatis Danubius. Economica, 15 (2), 93-114.

48. Niu, Y., Dong, L. C., \& Chen, R. (2012). Market entry barriers in China. Journal of Business Research, 65(1), 68-76. Doi:10.1016/j. jbusres.2011.01.018

49. Pehrsson, A. (2004). Strategy competence: a successful approach to international market entry. Management Decision, 42(6), 758-768. Doi:10.1108/00251740410542320

50. Porter, M. (1979). How Competitive Forces Shape Strategy Harvard Business Review, March-April, 137-145.

51. Porter, M. E. (1980). Competitive strategy: Techniques for analyzing industries and competitors. New York: Free Press.

52. Porter, M. E. (1985). Technology and competitive advantage. Journal of business strategy, 5(3), 60-78.

53. Porter, M. E. (2008). The five competitive forces that shape strategy. Harvard business review, 86(1), 25-40.

54. Pulaj, E., (2014). Atraktiviteti i industrisë së ndërtimit nga këndvështrimi i strategjive konkurruese të porter-it. Universiteti i Tiranës - Fakulteti i ekonomisë - Departamenti i menaxhimit [The attractiveness of the construction industry from the perspective of porter's competitive strategies. University of Tirana - Faculty of Economics - Department of Management].

55. Pustay, M. W. (1985). Reform of Entry into Motor Carrier Markets: Was the Motor Carrier Act of 1980 Necessary?. Transportation journal, 25(1), 11-24.

56. Reed, O. L. (1975). The Psychological Impact of TV Advertising and the need for FTC Regulation. American Business Law Journal, 13(2), 171183. Doi:10.1111/j.1744-1714.1975. tb00973.x

57. Scherer, F. M. (1970). Industrial pricing: Theory and evidence. Rand McNally \& Company.

58. Schlegelmilch, B. B., \& Ambos, B. (2004). Multi-utility: strategic option in deregulated markets? An empirical assessment using conjoint analysis. Journal of Strategic Marketing, 12(1), 57-68. Doi:10.1080/0965254032000171591

59. Schmalensee, R. (1981). Economies of scale and barriers to entry. Journal of political Economy, 89(6), 1228-1238. Doi:10.1086/261031

60. Schmalensee, R. (1982). Product differentiation advantages of pioneering brands. The American Economic Review, 72(3), 349-365.

61. Schmalensee, R. (1983). Advertising and entry deterrence: an exploratory model. Journal of political Economy, 91(4), 636-653. Doi:10.1086/261169

62. Shepherd, W. G. (1975). The treatment of market power: Antitrust, regulation, and public enterprise. Columbia University Press.

63. Spence, A. M. (1980). Notes on advertising, economies of scale, and 
entry barriers. The quarterly journal of Economics, 95(3), 493-507. Doi: $10.2307 / 1885090$

64. Stigler, G. (1968). Barriers to entry, economies of scale, and firm size, the organization of industry. Homewood, IL: Irwin.

65. Von Weizsacker, C. C. (1980). A welfare analysis of barriers to entry. The bell journal of economics, 399-420. Doi: $10.2307 / 3003371$

66. Wheelen, T. L., \& Hunger, J. D. (2011). Strategic management and business policy: toward global sustainability. Pearson/Prentice Hall.

67. Yip, G. S. (1982). Barriers to entry: A corporate-strategy perspective. Lexington: Lexington Books.

\section{ULAZNE BARIJERE I ULAZAK NOVIH PODUZEĆA NA KONKURENTNA TRŽIŠTA U ODNOSU NA PROFITABILNOST POSTOJEĆIH KONKURENATA}

Sažetak. U posljednje je vrijeme ulazak novih poduzeća na konkurentna tržišta sve težu zbog različitih industrijskih barijera. Ovaj rad tretira navedenu problematiku te kao svoj cilj postavlja mjerenje odnosa između industrijskih barijera, koje sprečavaju ulaz novih rivala te povećanja profitabilnosti postojećih konkurenata. Studija se temelji na podacima, dobivenih od 107 menadžera poduzeća, koja posluju na području Republike Kosovo, pri čemu pokušava potvrditi i po značaju poredati barijere za ulaz na tržište. Odgovori su prikupljeni putem upitnika, a za testiranje prethodno opisane veze, konstruiran je ekonometrijski model. Rezultati istraživanja su dobiveni korištenjem deskriptivne statistike, Pearsonovog koeficijenta korelacije i multivarijantne regresije.
Ekonometrijski rezultati ukazuju da sedam dimenzija industrijskih barijera imaju direktan $i$ pozitivan utjecaj na profitabilnost postojećih konkurenata te da predstavljaju barijere novim poduzećima za ulazak na tržište. Također se pokazuje da menadžeri na Kosovu percipiraju kapitalne zahtjeve, koji se postavljaju pred nova poduzeća, kao najznačajniju ulaznu barijeru, dok je pristup distribucijskim kanalima najmanje važan. U radu se diskutiraju dobiveni rezultati $i$ objašnjavaju njihove teorijske te praktične implikacije.

Ključne riječi: ulazne barijere, nova poduzeća, industrijski čimbenici, profitabilnost postojećih konkurenata, konkurentno tržište. 


\section{APPENDIX A}

\section{ITEMS USED FOR THE IMPORTANCE OF INDUSTRY BARRIERS}

With regard to industry factors that hinder your rivals to entry in the competitive market, please circle the appropriate number to indicate the extent to which you agree or disagree with each statement.

The item scales are five-point Likert type scales with 1 -not important at all, 2-not important, 3 -neutral, 4 -important, 5 -extremely important.

\begin{tabular}{|l|l|}
\hline 1. Perceived importance of factors that may serve as barriers for new firms \\
\hline $\mathrm{BoE}_{1}$ & In industry, existing firms have loyal consumers. \\
$\mathrm{BoE}_{2}$ & Existing firms have appropriate channels for their product's distribution. \\
$\mathrm{BoE}_{3}$ & A certain number of firms have appropriate location for this industry. \\
$\mathrm{BoE}_{4}$ & In order to enter in the industry, it is needed a high amount of capital. \\
$\mathrm{BoE}_{5}$ & Current firms can offer lower prices than new firms. \\
$\mathrm{BoE}_{6}$ & New entries must invest more in buildings, equipment and machineries. \\
$\mathrm{BoE}_{7}$ & Our clients do not prefer to shift for small differences in quality/price. \\
$\mathrm{BoE}_{8}$ & New entries are defined from law and governmental rules. \\
$\mathrm{BoE}_{9}$ & A huge number of new firms have entered in the market last years. \\
$\mathrm{BoE}_{10}$ & Competitors react with special offers and lowering the prices toward new entries. \\
$\mathrm{BoE}_{11}$ & Firms operating in this industry have excess capacity and inventory. \\
\end{tabular}

With regard to industry factors that increase your firm profitability, please circle the appropriate number to indicate the extent to which you agree or disagree with each statement.

The item scales are five-point Likert type scales with 1 - not important at all, 2 - not important, 3 neutral, 4 -important, 5 -extremely important.

2. Perceived importance of dimensions that may increase incumbent firms profitability

Economies of scale

\begin{tabular}{|l|l|}
\hline $\mathrm{ES}_{\mathrm{LA}}$ & The large amounts of products decrease the cost for unit. \\
\hline $\mathrm{ES} / \mathrm{LC}_{2}$ & Incumbent with cost advantage due to learning curve. \\
\hline $\begin{array}{l}\mathrm{ES} / \mathrm{CA}_{3} \\
\mathrm{ES} / \mathrm{P}_{4}\end{array}$ & $\begin{array}{l}\text { Incumbent with cost advantage due to economies of scale. } \\
\text { Low price charged by incumbents as a result of low cost of production. }\end{array}$ \\
\hline Product differentiation of incumbents \\
\hline $\mathrm{PDI} / \mathrm{HA}_{1}$ & Heavy advertising by firms already in the market. \\
\hline $\mathrm{PDI} / \mathrm{PC}_{2}$ & Possession of channel members. \\
\hline $\mathrm{PDI} / \mathrm{BN}_{3}$ & Brand name or trademark. \\
\hline $\begin{array}{l}\mathrm{PDI} / \mathrm{BA}_{4} \\
\mathrm{PDI} / \mathrm{SP}_{5}\end{array}$ & $\begin{array}{l}\text { Brand awareness advantage held by incumbents. } \\
\text { Incumbent with superior production process. }\end{array}$ \\
\hline Capital requirements of non-incumbents \\
\hline $\mathrm{CR} / \mathrm{AE}_{1}$ & Amount of selling expense involved in marketing a product. \\
\hline $\mathrm{CR} / \mathrm{CE}_{2}$ & Cost of establishing branch office. \\
\hline
\end{tabular}




\begin{tabular}{|c|c|}
\hline $\begin{array}{l}\mathrm{CR} / \mathrm{RD}_{3} \\
\mathrm{CR} / \mathrm{SC}_{4} \\
\mathrm{CR} / \mathrm{BS}_{5}^{*}\end{array}$ & $\begin{array}{l}\text { Research and development expense involved in entering a market. } \\
\text { The amount of sunk cost involved in entering a market. } \\
\text { Business standards set by incumbents. }\end{array}$ \\
\hline \multicolumn{2}{|c|}{ Switching cost } \\
\hline $\mathrm{SC} / \mathrm{CS}_{1}$ & Customers' cost associated with switching from one supplier to another. \\
\hline $\mathrm{SC} / \mathrm{CL}_{2}$ & Consumer loyalty advantage held by incumbents. \\
\hline $\begin{array}{l}\mathrm{SC} / \mathrm{EP}_{3} \\
\mathrm{SC} / \mathrm{SC}_{4}^{*}\end{array}$ & $\begin{array}{l}\text { Expected post-entry reaction of incumbents. } \\
\text { Seller confrontation. }\end{array}$ \\
\hline \multicolumn{2}{|c|}{ Access to distribution channels } \\
\hline $\mathrm{ADC} / \mathrm{AD}_{1}$ & Accessibility of distribution channels. \\
\hline $\mathrm{ADC} / \mathrm{CC}_{2}$ & Channel construction expenses for new firms. \\
\hline $\begin{array}{l}\mathrm{ADC} / \mathrm{MM}_{3} \\
\mathrm{ADC} / \mathrm{NF}_{4}\end{array}$ & $\begin{array}{l}\text { Magnitude of market share held by incumbents. } \\
\text { Number of firms present in the market restricts new firms' access to the channel. }\end{array}$ \\
\hline \multicolumn{2}{|c|}{ Cost disadvantages independent of size } \\
\hline $\mathrm{CD} / \mathrm{IP}_{1}$ & Incumbents possessing strategic raw marterials. \\
\hline $\mathrm{CD} / \mathrm{IR}_{2}$ & Incumbents with relativly easy assess to raw materials. \\
\hline $\mathrm{CD} / \mathrm{IP}_{3}$ & Incumbents with proprietary product technology. \\
\hline $\mathrm{CD} / \mathrm{TS}_{4}$ & Trade secrets held by competitors. \\
\hline \multicolumn{2}{|c|}{ Government policy } \\
\hline $\mathrm{GP} / \mathrm{EP}_{1}$ & Environment protection and tariffs. \\
\hline $\mathrm{GP} / \mathrm{GL}_{2}$ & Government licensing requirements for new firms. \\
\hline $\mathrm{GP} / \mathrm{GS}_{3}$ & Incumbents with government subsidies. \\
\hline
\end{tabular}

"How do you evaluate the impact of these dimensions on your firm profitability. The item scales are five-point Likert scales with 1 = significant decrease, $2=$ decrease, $3=$ same as before, $4=$ increase, $5=$ significant increase."

\begin{tabular}{|l|l|}
\hline \multicolumn{2}{|l|}{ Profitability of incumbents } \\
\hline $\mathrm{PI}_{1}$ & Market share. \\
\hline $\mathrm{PI}_{2}$ & The growth of sales. \\
\hline $\mathrm{PI}_{3}$ & Overall competitive position. \\
\hline
\end{tabular}

Note: Items marked by an asterisk (*) were removed in the final measurement. 
